\title{
Makrozoobentos Sebagai Indikator Biologis dalam Menentukan Kualitas Air Sungai Suhuyon Sulawesi Utara
}

\author{
Sernando Rizky Nangina*, Marnix L. Langoya, Deidy Y. Katilia \\ aJurusan Biologi, FMIPA, Unsrat, Manado
}

\begin{tabular}{|c|c|}
\hline KATA KUNCI & A B S TR A K \\
\hline $\begin{array}{l}\text { makrozoobentos } \\
\text { indikator biologis } \\
\text { Sungai Suhuyon }\end{array}$ & $\begin{array}{l}\text { Makrozoobentos dapat digunakan sebagai parameter biologis dalam } \\
\text { menentukan kualitas sungai karena hidupnya relatif diam di dasar sungai. } \\
\text { Penelitian ini bertujuan untuk menentukan kualitas air Sungai Suhuyon } \\
\text { Sulawesi Utara berdasarkan indeks keanekaragaman makrozoobentos. } \\
\text { Penelitian dilakukan pada musim panas yaitu bulan Mei sampai Juni } \\
2015 \text {. Lokasi penelitian ditentukan dari bagian hulu, tengah dan hilir } \\
\text { sungai dengan } 3 \text { ulangan di setiap lokasi. Kualitas air Sungai Suhuyon } \\
\text { ditentukan berdasarkan indeks keanekaragaman makrozoobentos } \\
\text { Shannon Wiener (H') menurut kriteria Wilhm (1975). Makrozoobentos di } \\
\text { Sungai Suhuyon terdiri dari } 3 \text { Filum, } 4 \text { Kelas, } 10 \text { Bangsa, } 21 \text { Suku dan } 22 \\
\text { Marga. Kualitas air Sungai Suhuyon Sulawesi Utara berdasarkan indeks } \\
\text { keanekaragaman termasuk dalam kategori tercemar sedang }\left(H^{\prime}=2,45\right) \text {. }\end{array}$ \\
\hline KEYWORDS & A B S T R A C T \\
\hline $\begin{array}{l}\text { macrozoobenthos } \\
\text { biological indicator } \\
\text { Suhuyon river }\end{array}$ & $\begin{array}{l}\text { Macrozoobenthos can be used as a biological parameter in determining } \\
\text { water quality of the river because they relatively stick on the riverbed. This } \\
\text { study aims to determine water quality of Suhuyon river in North Sulawesi } \\
\text { based on macrozoobenthos biodiversity index. The study was conducted } \\
\text { during dry season, from May to June } 2015 \text {. Three locations chosen for this } \\
\text { study were the upstream, midstream and downstream part of the river, } \\
\text { with } 3 \text { replications in each location. The quality of Suhuyon river was } \\
\text { determined by Shannon Wiener biodiversity index (H') of macrozoobenthos } \\
\text { using classification of Wilhm (1975). Macrozoobenthos in Suhuyon river } \\
\text { consisted of } 3 \text { Phylum, } 4 \text { Classes, } 10 \text { Orders, } 21 \text { Families and } 22 \text { Genus. } \\
\text { Based on biodiversity index, water quality of Suhuyon River is categorized } \\
\text { into moderately polluted }\left(\mathrm{H}^{\prime}=2.45\right) \text {. }\end{array}$ \\
\hline
\end{tabular}

TERSEDIA ONLINE

10 Oktober 2015

\begin{abstract}
1. Pendahuluan
Sungai merupakan salah satu ekosistem lotik (perairan mengalir) memiliki fungsi sebagai tempat hidup organisme (Maryono, 2005). Organisme yang hidup dalam perairan sungai adalah organisme yang telah memiliki kemampuan untuk beradaptasi terhadap kecepatan arus (Susanto dan Rochidanto, 2008). Sungai merupakan salah satu lingkungan yang sering terkena dampak pencemaran. Pencemaran dapat disebabkan karena berbagai jenis aktivitas manusia yang dilakukan di sepanjang daerah aliran sungai. Meningkatnya aktivitas
\end{abstract}

domestik, pertanian dan industri akan mempengaruhi dan berdampak buruk terhadap kondisi kualitas air sungai (Priyambada et al., 2008).

Sungai Suhuyon merupakan salah satu anak sungai di Sulawesi Utara dan merupakan anak Sungai Ranoyapo. Penelitian dilakukan di Sungai Suhuyon karena merupakan sungai yang potensial dan bermanfaat bagi masyarakat setempat. Sungai Suhuyon merupakan salah satu sungai di Sulawesi Utara yang rentan terhadap pencemaran. Pencemaran dapat terjadi karena tingginya aktivitas manusia yang dilakukan mulai dari bagian hulu

\footnotetext{
*Corresponding author: Jurusan Biologi FMIPA UNSRAT, Jl. Kampus Unsrat, Manado, Indonesia 95115; Email address: nanginsernando@gmail.com Published by FMIPA UNSRAT (2015)
} 
sampai ke hilir sungai. Meningkatnya aktivitas domestik, pertanian serta penambangan batu yang dilakukan di Sungai Suhuyon mengakibatkan perubahan kualitas air sungai yang mencakup perubahan sifat fisika, kimia maupun biologi sungai (Priyambada et al., 2008).

Penurunan kualitas air sungai akan diikuti dengan perubahan kondisi fisik, kimia dan biologis sungai. Perubahan yang terjadi akan berdampak pada kerusakan habitat dan mengakibatkan penurunan keanekaragaman organisme yang hidup pada perairan sungai termasuk di dalamnya komunitas makrozoobentos. Makrozoobentos merupakan salah satu komponen biotik yang dapat memberikan gambaran mengenai kondisi perairan sungai (Odum, 1996). Makrozoobentos terdapat diseluruh badan sungai mulai dari hulu sampai ke hilir. Makrozoobentos merupakan salah satu organisme akuatik yang menetap di dasar perairan, yang memiliki pergerakan relatif lambat serta dapat hidup relatif lama sehingga memiliki kemampuan untuk merespon kondisi kualitas perairan sungai (Zulkifli dan Setiawan, 2011).

Bioindikator belakangan ini dirasakan sangat penting untuk memperlihatkan adanya keterkaitan antara faktor biotik dan abiotik suatu lingkungan. Bioindikator atau indikator ekologis merupakan suatu kelompok organisme yang hidup dan rentan terhadap perubahan lingkungan sebagai akibat dari aktivitas manusia dan kerusakan secara alami (Sumenge, 2008).

Pada saat ini data yang tersedia untuk keanekaragaman makrozoobentos di sungai Suhuyon masih kurang. Keanekaragaman makrozoobentos dirasakan sangat penting karena dapat memberikan informasi status kualitas air sungai apakah sudah atau belum tercemar. Penelitian untuk penentuan faktor fisika-kimia air sungai Suhuyon melalui serangkaian pengamatan dan perhitungan indeks keanekaragaman makrozoobentos dirasakan sangat penting. Penentuan status kualitas air Sungai Suhuyon diperlukan dalam upaya untuk memelihara dan menjaga kesehatan lingkungan serta pengelolaannya bagi kesejahteraan masyarakat setempat maupun untuk keberlanjutan kehidupan biota yang mendiami sungai tersebut.

\section{Metode}

Penelitian dilaksanakan pada bulan Mei sampai Juni 2015. Penelitian dilakukan pada 3 bagian Sungai Suhuyon, yaitu hulu (Stasiun 1), tengah (Stasiun 2) dan hilir (Stasiun 3). Untuk identifikasi sampel dilakukan di laboratorium Ekologi F-MIPA UNSRAT. Alat dan bahan yang digunakan yaitu meteran, termometer, botol, kertas $\mathrm{pH}$, tali, stopwatch, GPS (Global Positioning System), gabus, aquameter, keping seci, kamera, lup, pipet, kuas, mikroskop, alat tulis, cawan petri, surber dan alkohol 70\%. Metode yang digunakan untuk pengambilan sampel makrozoobentos yaitu metode purposive random sampling yaitu metode pencuplikan yang dilakukan secara sengaja.

Pengambilan dari contoh makrozoobentos dilakukan dengan menggunakan surber sampler di dasar perairan sungai dengan cara mengeruk bagian luasan petak. Hal tersebut dilakukan agar hewan bentos yang berada di dasar sungai maupun yang menempel pada bebatuan dapat terbawa arus dan masuk ke surber sampler. Sampel yang didapatkan di lapangan diidentifikasi di laboratorium Ekologi dan Konservasi F-MIPA UNSRAT dengan menggunakan Mikroskop dan lup (kaca pembesar). Buku identifikasi yang digunakan yaitu (Borror et al.,1996 dan Edmondson, 1966).

Untuk mengetahui indeks keanekaragaman (H') menggunakan rumus Shannon dan Weaner (Fachrul, 2007):

$$
\left(\mathrm{H}^{\prime}\right)=-\sum_{i=l}^{s} \mathrm{P}_{\mathrm{i}} \ln \mathrm{P}_{\mathrm{i}}
$$

Keterangan :

$\mathrm{Pi}=n i / N$ (rasio jumlah individu satu marga terhadap keseluruhan marga)

$\mathrm{H}^{\prime}=$ penduga keragaman populasi

Dalam Wilh (1975), kriteria nilai indeks menurut Shannon:

$\mathrm{H}^{\prime}<1=$ tercemar atau kualitas air tercemar berat

H 1-3 = stabilitas komunitas biota sedang atau air tercemar sedang

$\mathrm{H}^{\prime}>3$ = stabilitas komunitas biota dalam kondisi prima (stabil) atau kualitas air bersih

\section{Hasil dan Pembahasan}

Total individu yang didapatkan dari 3 stasiun sebanyak 262 individu yang terdiri dari 3 filum, 4 kelas, 10 bangsa, 21 suku, dan 22 marga. Pada stasiun 1 (Hulu) didapatkan 17 marga dengan total individu sebanyak 120. Stasiun 2 (Tengah) didapatkan 13 marga dengan individu sebanyak 98, sedangkan hilir sungai (Stasiun 3) diperoleh total individu sebanyak 44 dari 10 marga. Marga yang paling banyak ditemukan adalah Hydropsyche, Acroneuria dan yang paling sedikit ditemukan adalah Luciolla, Atherix, Mysis dan Gerris. Keanekaragaman, kelimpahan dan kekayaan makrozoobentos pada setiap stasiun erat kaitannya dengan faktor lingkungan yang terdapat pada masing-masing stasiun. Makrozoobentos yang ditemukan di setiap stasiun penelitian keberadaannya berasal dari penyesuaian terhadap kondisi lingkungan (Noortiningsih et al., 2008).

Indeks keanekaragaman ( $\left.\mathrm{H}^{\prime}\right)$ makrozoobentos yang di dapatkan di Sungai Suhuyon yaitu 2,45. Wilhm (1975), menggolongkan tingkat pencemaran sungai berdasarkan indeks keanekaragaman yaitu tercemar sangat ringan, tercemar sedang, dan tercemar berat dengan indeks keanekaragaman $>3$; 1 - 3 dan <1. Berdasarkan pengelompokkan tersebut, kualitas air Sungai Suhuyon Berdasarkan indeks keanekaragaman makrozoobentos termasuk 
ke dalam perairan tercemar sedang. Menurut Simamora (2012), semakin tinggi nilai indeks keanekaragaman sungai maka semakin rendah pula tingkat pencemarannya. Substrat dasar perairan berbatu, kecepatan arus tinggi, suhu $\left(24^{\circ} \mathrm{C}\right.$ - $26^{\circ} \mathrm{C}$ ) penetrasi cahaya sampai ke dasar sungai merupakan tipe habitat yang disukai oleh makrozoobentos.

Makrozoobentos yang ditemukan di hulu sungai (stasiun 1) terdapat 7 bangsa yaitu; Coleoptera, Trichoptera, Diptera, Ephemeroptera, Plecoptera, Odonata, dan Hemiptera. Bangsa yang paling dominan adalah Ephemeroptera karena dari bangsa ini menempatkan 5 marga makrozoobentos yang ditemukan. Makrozoobentos yang ditemukan di stasiun 1 yaitu: Anthopotamus, Stenonema, Epeorus, Habrophlebia, Baetis, Dubiraphia, Psephenus, Chimarra, Atherix, Simulium, Acroneuria, Pteronarcys, Rhangovelia, Orthetrum, Libellago, Hydropsyche, dan Prosopistoma. Makrozoobentos yang ditemukan di hulu sungai termasuk ke dalam filum Arthropoda, kelas Insekta. Kelimpahan makrozoobentos dari filum Arthtropoda yang ditemukan dibagian hulu dan tengah sungai disebabkan karena adanya kondisi lingkungan yang mendukung seperti suhu $\left(24^{\circ} \mathrm{C}-26^{\circ} \mathrm{C}\right)$, kecepatan arus tinggi, $\mathrm{pH}$ air (6 - 7), penetrasi cahaya sampai ke dasar sungai serta substrat dasar perairan berbatu. Keberadaan bangsa Ephemeroptera, Plecoptera dan Trichoptera menunjukkan bahwa perairan masih berkualitas baik (Merrit dan Cummins, 1996).

Makrozoobentos yang ditemukan di stasiun 2 terdapat 8 bangsa yaitu; Decapoda, Coleoptera, Trichoptera, Diptera, Ephemeroptera, Plecoptera, Odonata, dan Hemiptera. Kelimpahan makrozoobentos yang ditemukan di Stasiun 2 karena adanya kondisi lingkungan yang mendukung (Siregar, 2010). Makrozoobentos yang ditemukan di stasiun 2 yaitu: Mysis, Psephenus, Simulium, Anthopotamus, Stenonema, Habrophlebia, Baetis, Acroneuria, Rhangovelia, Orthetrum, Hydropsyche, Gerris, dan Prosopistoma. Makrozoobentos yang ditemukan di stasiun 2 termasuk ke dalam filum Arthropoda kelas Crustaceae dan insekta. Kelimpahan bangsa Plecoptera di hulu dan tengah sungai disebabkan karena makrozoobentos dari bangsa ini menyukai substrat dasar perairan yang berbatu (Marmita, 2013).

Makrozoobentos yang ditemukan di hiilir sungai (Stasiun 3) terdapat 7 bangsa yaitu: Coleoptera, Ephemeroptera, Plecoptera, Hemiptera, Veneroida, Haplotaxida, dan Trichoptera. Masing-masing bangsa berasal dari tiga kelas yang berbeda yaitu kelas Insekta, Pelecypoda, dan Oligochaeta. Makrozoobentos yang ditemukan di stasiun 3 yaitu: Dubiraphia, Psephenus, Baetis, Stenonema, Acroneuria, Rhangovelia, Sphaerium, Tubifex, Luciolla, dan Hydropsyche. Semakin ke hilir kelimpahan dan kekayaan makrozoobentos semakin rendah. Penurunan kualitas air sungai mempengaruhi kehadiran makrozoobentos. Stasiun 3 (Hilir sungai) memiliki penetrasi cahaya yang tidak sampai ke dasar sungai, kecepatan arusnya lambat dan memiliki substrat dasar yang berlumpur, dimana keadaan tersebut kurang disukai oleh makrozoobentos.

Distrbusi dari makrozoobentos yang ditemukan cukup bervariasi dari ketiga stasiun penelitian. Makrozoobentos yang dapat ditemukan pada ketiga stasiun yaitu: Psephenus, Stenonema, Baetis, Acroneuria, Rhangovelia, dan Hydropsyche. Menurut Vionskiene (2005), Kehadiran bangsa Trichoptera marga Hydropsche, dan bangsa Ephemeroptera marga Baetis pada stasiun 3 menandakan bahwa kedua marga ini mampu beradaptasi terhadap perubahan lingkungan yang terjadi. Pada stasiun 2 makrozoobentos yang ditemukan hampir semua dapat ditemukan di stasiun 1 sedangkan pada stasiun 3 kehadiran Tubifex yang termasuk ke dalam filum Annelida tidak dapat di jumpai pada stasiun 1 dan 2. Hilir sungai (Stasiun 3) kehadiran marga Tubifex yang berasal dari filum Annelida menandakan bahwa lingkungan tersebut telah tercemar (Sastrawijaya, 2009). Kehadiran Tubifex di Stasiun 3 merupakan indikator pencemaran bahan organik karena jenis ini sangat toleran terhadap kandungan oksigen terlarut yang rendah dan partikel tersuspensi yang tinggi dalam sungai.

\section{Kesimpulan}

Makrozoobentos yang ditemukan di Sungai Suhuyon terdiri dari 3 filum, 4 kelas, 10 bangsa, 21 suku dan 22 marga. Berdasarkan indeks keanekaragaman makrozoobentos (H') kualitas air sungai Suhuyon termasuk ke dalam kelompok perairan tercemar sedang. Berdasarkan PP No. 82 Tahun 2001 air pada Sungai Suhuyon tidak dapat digunakan sebagai air minum (Baku mutu Air Kelas 1). Air pada sungai Suhuyon hanya dapat digunakan dalam sistem pengairan, budidaya ikan air tawar dan sarana rekreasi air.

\section{Daftar Pustaka}

Boror, D. J, C., A., Triplohofi , N, F. Johnson 1996. Pengenalan pelajaran serangga edisi keenam . Gadjah Mada University Press. Yogyakarta.

Edmondson, W.T. 1966. Freshwater Biology. Second Edition. University of Washington. Seattle.

Fachrul, M.F. 2007. Metode Sampling Bioteknologi. Bumi Aksara. Jakarta.

Marmita, R. 2013. Makrozoobentos Sebagai Indikator Biologis Dalam Menentukan Kualitas Air Sungai Ranoyapo Minahasa Selatan, Sulawesi Utara. [Skripsi]. Universitas Samratulangi, Manado.

Maryono, A. 2005. Ecological Hydraulics of River Development. Edisi Kedua. Magister Sistem Teknik Program Pascasarjana Universitas Gajah Mada, Yogyakarta. 
Merritt, R. W dan Cummins,. K, W. 1996. An Introduction To The Aquatic Insects Of North America. New York; Kendall/ Hunt Publishing Company.

Noortiningsih. Ikna, S. Sri H. 2008. Keanekaragaman Makrozoobentos, Meiofauna, dan Foraminifera di Pantai Pasir Putih Barat dan Muara Sungai Cikamal Pangandaran, Jawa Barat. Jurnal Vis Vitalis. 01(1): 34-42.

Odum, E. P. 1996. Dasar-dasar Ekologi. Edisi Ketiga. Gajah Mada University Press, Yogyakarta.

Priyambada, I. B., Oktiawan W, dan R.P.E Suprapto. 2008. "Analisa Pengaruh Perbedaan Fungsi Tata Guna Lahan Terhadap Beban Pencemaran BOD Sungai (Studi Kasus Sungai Serayu Jawa Tengah)". Jurnal Presipitasi, 5. 55-62.

Sastrawijaya, A. T. 2009. Pencemaran Lingkungan. Rineka Cipta, Surabaya.
Sumenge, V. 2008. Penentuan Kualitas Air Sungai Sendangan Kakas Dengan Bioindikator Keanekaragaman Serangga Air. [Skripsi]. Universitas Samratulangi, Manado.

Susanto, H. dan A. Rochdianto. 2008. Kiat Budi Daya Ikan Mas Dilahan Kritis. Penebar Swadaya Depok. Jakarta.

Vioinskiene, G. 2005. Biodiversity, Distribution and Ecology Of Macrozoobentos In Small Lithuanian Rivers. Institute of Ecology of Vilnius University.

Wilhm, J. L. 1975. Biological Indicator of Poluttion. In: B. A. Whitton (Edtor). River Ecology. Blackwell Scietific Publications, Oxford. 375-402 pp.

Zulkifli, H dan Setiawan, D. 2011. Struktur dan Fungsi Komunitas Makrozoobentos di perairan Sungai Musi Kawasan Pulokerto sebagai Instrumen Biomonitoring. Jurnal Natur Indonesia. 14(1): 95-99. 